\title{
Tata Kelola Organisasi Mahasiswa Melalui Pengembangan Sistem Informasi
}

\section{Student Organization Governance Through the Development of Information System}

\author{
Ellen Theresia Sihotang ${ }^{1}$, Hariadi Yutanto ${ }^{2}$ \\ ${ }^{1}$ Universitas Hayam Wuruk Perbanas, Indonesia
}

\section{Informasi Artikel}

\section{Genesis Artikel:}

Diterima, 12 Agustus 2021

Direvisi, 17 Oktober 2021

Disetujui, 20 Oktober 2021

\section{Kata Kunci:}

Sistem Informasi

Organisasi Mahasiswa

Ormawasite

Web

\section{Keywords:}

Information System

Student Organization

Ormawasite

Website

\begin{abstract}
ABSTRAK
Sistem informasi Organisasi Mahasiswa (Ormawa) Universitas Hayam Wuruk (UHW) Perbanas Surabaya yang menggunakan google drive sudah tidak efektif dan tidak efisien dalam pelaksanaan kegiatan kemahasiswaan. Kondisi pandemi juga tidak memungkinkan Ormawa untuk menggunakan sistem berbasis cloud sehingga diperlukan sistem yang bersifat online dan terintegrasi. Tujuan dari penelitian ini adalah untuk mengembangkan sistem informasi Ormawa berbasis web dengan jaringan online dengan nama Ormawasite. Fokus pengembangannya adalah pada pengelolaan sejumlah dokumen aktivitas dan keuangan ormawa. Metode pengembangan Ormawasite menggunakan System Development Life Cycle (SDLC) dengan model waterfall. Tahapan-tahapan pada model waterfall meliputi analisis kebutuhan melalui kelompok diskusi fokus, rancangan sistem, coding, implementasi sekaligus uji coba sistem dengan metode black box dan evaluasi penggunaan Ormawasite menggunakan kuesioner dengan skala likert. Bahasa pemrograman yang digunakan adalah HTML 5, PHP 7.0.18, dan terintegrasi dengan Sistem Informasi Mahasiswa (Simas) serta bagian kemahasiswaan. Ormawasite telah membantu pelaksanaan program kerja Ormawa dan pengelolaan keuangan. Pengelolaan aktivitas dan keuangan yang sebelumnya selama tujuh hari menjadi satu hari dan aksesnya lebih fleksibel, dengan demikian penggunaan Ormawasite menjadi lebih efektif dan efisien.
\end{abstract}

\section{ABSTRACT}

The information system of student organization of Hayam Wuruk University (UHW) Perbanas Surabaya which used google drive is no longer effective and efficient in implementation of student activities. The pandemic also no longer possible for student organizations to use a cloud-based system, hence an online and integrated system is needed. The aim of this study is to develop a web-based Student Organization information system with an online network under the name Ormawasite. The focus of its development is on managing a number of financial and activity documents. The Ormawasite development method uses the System Development Life Cycle (SDLC) with the waterfall model. The stages in the waterfall model include needs analysis through Focus Group Discussion (FGD), system design, coding, implementation, as well as system testing with the black box and evaluation of use of Ormawaite using a questionnaire with a likert scale. The programming language used is HTML 5, PHP 7.0.18 and integrated with the Student Information System (Simas) and student affair. The management of activities and finances that were previously seven days into one day and access is more flexsible, thus the use of Ormawasite becomes more effective and efficient.

This is an open access article under the CC BY-SA license.

\section{Penulis Korespondensi:}

Ellen Theresia Sihotang, Program Studi Manajemen, Universitas Hayam Wuruk Perbanas, Email: ellen@perbanas.ac.id 


\section{PENDAHULUAN}

Perkembangan teknologi yang cukup pesat telah memberikan perubahan pada tata kelola sejumlah aktivitas organisasi pada sektor perdagangan, industri, pemerintahan maupun pendidikan. Sejumlah aktivitas yang sebelumnya dijalankan secara manual kini mulai diubah dalam bentuk digital, dalam rangka memberikan kemudahan dan efisiensi waktu pada penyelesaian sejumlah pekerjaan [1]. Kemudahan dan ketepatan penyelesaian pekerjaan juga menjadi alasan mendasar sejumlah organisasi untuk mengimplementasi sistem informasi, karena sistem informasi mampu untuk mengumpulkan, memproses serta mendistribusikan data secara terintegrasi dan tepat waktu [2], [3] sehingga aktivitas organisasi dapat berjalan secara efektif dan efiesien [4].

Sektor pendidikan pada saat ini juga sudah mengimplementasikan sistem informasi pada pelaksanaan kegiatannya, terutama pada institusi pendidikan tinggi. Pendidikan tinggi di Indonesia mengemban tiga tugas utama yang meliputi pengajaran, penelitian dan pengabdian masyarakat. Ketiga tugas utama tersebut dikenal dengan istilah Tri Dharma Perguruan Tinggi. Pelaksanaan ketiga tugas tersebut tidak terlepas dari peran mahasiswa sebagai bagian dari civitas akademik. Mahasiswa menjadi bagian yang berperan penting dalam pengelolaan suatu sistem karena menyimpan informasi dan menghasilkan laporan yang berkaitan dengan pengambilan keputusan [5]. Salah satu peran mahasiwa tersebut adalah pada pengelolaan Unit Kegiatan Mahasiswa (UKM) yang meliputi bidang seni, olahraga dan bidang lainnya. Sejumlah UKM tersebut berada dalam satu wadah organisasi yang disebut Organisasi Mahasiswa (Ormawa). Ormawa sebagai wadah kegiatan ekstra kurikuler memerlukan sistem informasi yang dapat mendukung pelaksanaan aktivitas, meliputi pelaporan, monitoring dan pengendalian beserta pendanaannya [2]. Aktivitas dan pendanaan Ormawa tersebut menjadi basis data bagi perguruan tinggi dalam rangka menetapkan keputusan strategis dan taktis dalam jangka panjang [6].

Sekolah Tinggi Ilmu Ekonomi (STIE) Perbanas yang telah melakukan transformasi menjadi Universitas Hayam Wuruk (UHW) Perbanas merupakan salah satu perguruan tinggi di kota Surabaya, Jawa Timur yang memiliki 23 UKM dalam satu wadah Ormawa. Pengelolaan Ormawa sejak 2016 telah menggunakan sistem informasi berbasis cloud, yaitu google drive. Penggunaan google drive berada dibawah pengawasan bagian kemahasiswaan. Jauh sebelum terjadi pandemi, pengelolaan kegiatan, monitoring dan pengendalian aktivitas Ormawa UHW Perbanas telah menggunakan sistem informasi. Namun, pada perkembangannya, penggunaan google drive tersebut masih menghadapi beberapa kendala. Kendala yang pertama adalah pada dokumentasi surat masuk dan keluar yang masih disimpan secara manual pada google drive. Kendala yang kedua berkaitan dengan proses pengajuan program kerja (proker) yang juga masih dilakukan secara manual. Berkaitan dengan pelaksanaan program kerja memerlukan sejumlah dana anggaran yang pengajuannya juga masih dilakukan secara manual dan ini menjadi kendala ketiga. Proses pengajuan dana anggaran proker berlangsung sampai dengan dua hari, apabila tidak ada revisi anggaran. Proses pengajuan dana anggaran dapat berlangsung lebih dari dua hari jika terjadi revisi. Kendala yang ke-empat, beberapa dokumen kegiatan Ormawa belum terhubung secara langsung dengan unit kerja kemahasiswaan. Empat kendala tersebut menyebabkan pelaksanaan sejumlah aktivitas Ormawa menjadi tidak efektif dan efisien bagi Ormawa sendiri maupun bagi unit kerja kemahasiswaan. Selain beberapa kendala tersebut, kondisi pandemi juga memicu Ormawa untuk menyesuaikan sejumlah aktivitasnya. Sejumlah proker Ormawa harus tetap dilaksanakan dengan memperhatikan protokol yang ditetapkan oleh pemerintah, salah satunya adalah menjaga jarak (social distance). Berkaitan dengan protokol tersebut maka sejumlah kegiatan mahasiswa tetap dapat dijalankan secara daring, tanpa harus datang ke kampus. Pada pelaksanaan aktivitas tersebut, tentunya monitoring dan pengendalian juga harus berjalan, sehingga diperlukan pengembangan sistem informasi yang bersifat terintegrasi berdasarkan kebutuhan dan keinginan dari sejumlah pemangku kepentingan, termasuk Ormawa, unit kemahasiswaan dan pihak-pihak manajemen UHW Perbanas Surabaya. Adapun yang menjadi tujuan dari penelitian ini adalah mengembangkan sistem informasi Ormawa UHW Perbanas Surabaya berdasarkan kebutuhan dan keinginan dari segenap pemangku kepentingan dalam rangka meningkatkan efektivitas dan efisiensi pengelolaan aktivitas dan pendanaan Ormawa. Efektivitas dan efisiensi berkaitan dengan pelaksanaan proker dan pendanaan secara cepat dan tepat waktu tanpa harus memerlukan upaya yang lama [7] secara khusus oleh Ormawa dan secara umum bagi pihak-pihak lain yang berkepentingan seperti bagian kemahasiswaan, dosen pendamping Ormawa maupun bagi manajemen perguruan tinggi.

Beberapa penelitian sebelummya telah melakukan penelitian terhadap pengembangan sistem informasi Ormawa. Penelitian sebelumnya berupa rancang bangun pada Sistem Informasi Budgeting Ormawa Unimus (SIBORMUS) berfokus pada pengelolaan dana anggaran Ormawa berbasis web namun dengan koneksi offline (local host). SIBORMUS menggunakan bahasa pemrograman HTML 5, PHP 5.4.19, Javascript 1.8.5 serta CSS 2 dengan model waterfall. Metode pengujian menggunakan black box untuk uji alpha dan uji beta menggunakan instrumen dengan skala likert [4]. Penelitian sebelumnya juga berkaitan dengan pengelolaan administrasi Ormawa di STIMK STIKOM Indonesia. Penelitian tersebut mengembangkan sistem Ormawa yang diberi nama SIMAWA, berbasis web namun jaringannya masih offline. Fokus penelitian tersebut adalah mengembangkan pengelolaan administrasi Ormawa yang terintegrasi dengan sistem penilaiannya. Sistem penilaian menggunakan metode Simple Additive Weighting (SAW). Rancangan sistemnya menggunakan metode Structured Analysis and Structrued Design (SASD) dengan alat bantunya berupa Statement of Purpose (SOP), Event List dan Data Flow Diagram (DFD). Basis datanya menggunakan Entity Relationship Diagram (ERD) [8]. Penelitian lainnya yang juga masih terkait dengan pengembangan sistem informasi Ormawa yang difokuskan pada pelaporan, evaluasi dan monitoring aktivitas Ormawa pada salah satu perguruan tinggi swasta di Bandung. Sistem informasinya berbasis web dan online namun lebih berfokus pada pengajuan anggaran, monitoring dan pelaporan aktivitas Ormawa. Pengembangan sistemnya menggunakan metode waterfall berdasarkan Voice of Customer (VOC) dan metode penggujian menggunakan black box [2]. Perbedaan mendasar dari penelitian ini dengan penelitian sebelumnya adalah pengembangan sistem yang terintegrasi dengan penambahan fitur-fitur pada pengelolaan aktivitas dan pendanaan Ormawa.Fokus pengembangan pada pengelolaan dokumen dan keuangan dalam rangka memperlancar pelaksanaan proker dan mempercepat pencairan dana anggaran. 
Adapun susunan penulisan dari penelitian ini meliputi pendahuluan, metode penelitian yang berisi tentang analisis kebutuhan, rancangan sistem, pengembangan sistem, pengujian, serta implementasi dan pemeliharaan. Bagian berikutnya adalah hasil dan analisis. Pada bagian hasil dan analisis terdiri dari use case diagram, activity diagram, Entity Relation Diagram (ERD), pengembangan sistem dan hasil ujian. Bagian terakhir dari isi penelitian ini adalah kesimpulan.

\section{METODE PENELITIAN}

Pengembangan sistem informasi Ormawa UHW Perbanas Surabaya memerlukan kerangka kerja panduan guna mengkonfigurasi dan memantau kemajuan pengembangan sistem pada semua tahapan siklus sistem. Pengembangan sistem menjadi salah satu aspek strategis terpusat yang nantinya akan berdampak pada efektivitas sistem dalam jangka panjang sehingga memerlukan rancangan sistem yang terstruktur [9]. Rancangan sistem yang bekerja secara berurutan adalah System Development Life Cycle (SDLC) sebagai metode yang digunakan pada studi ini, dengan model waterfall. Model waterfall merupakan model yang pada umumnya digunakan untuk membuat suatu perangkat lunak [2]. Model waterfall meliputi beberapa tahapan berurutan yang diawali dengan persyaratan sistem, persyaratan perangkat lunak, analisis, rancangan program, coding, uji coba dan pengoperasian [10]. Namun model tersebut dapat disederhanakan menjadi lima tahapan utama secara berurutan, meliputi analisis, rancangan, coding, uji coba dan implementasi [11]. Tahapan-tahapan model waterfall tercantum pada Gambar 1, perihal Model Waterfall.

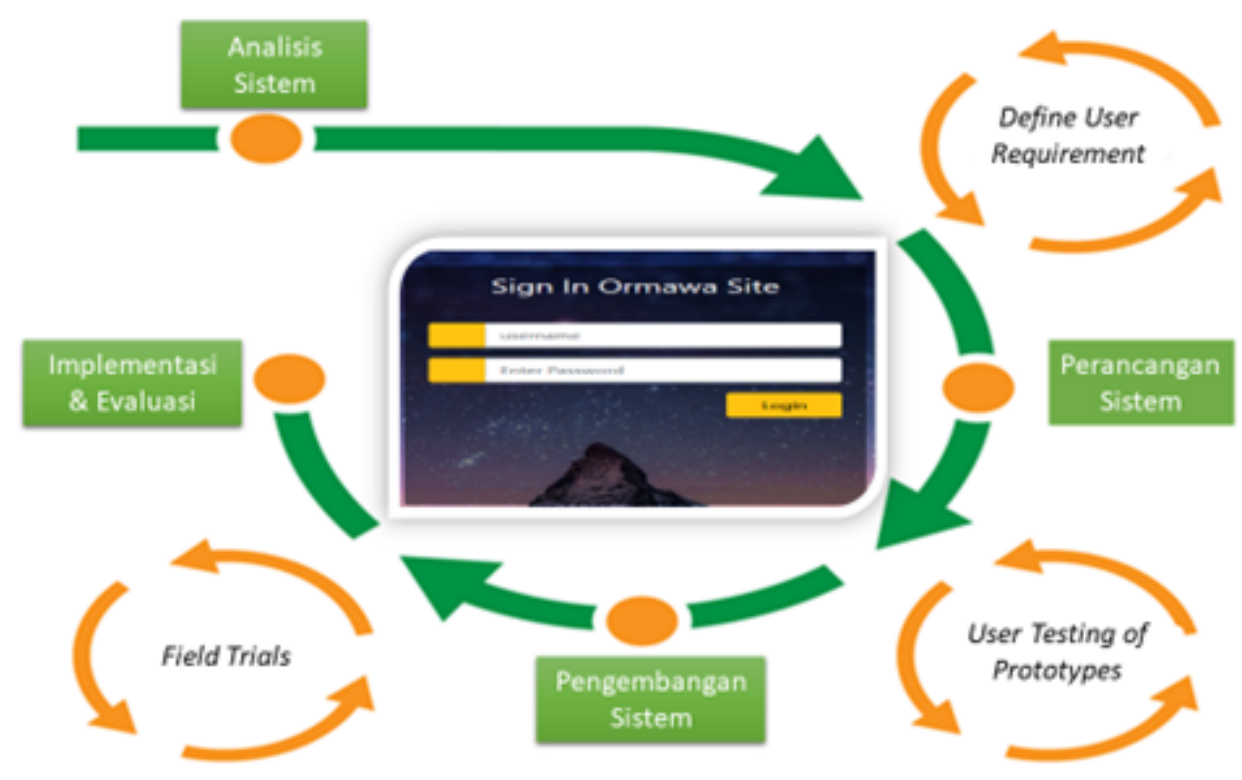

Gambar 1. Model Waterfall

\subsection{Analisis Kebutuhan}

Tahapan awal dilakukan melalui kelompok diskusi fokus (Focus Group Discussion/FGD) dan studi literatur. Kelompok diskusi fokus bertujuan untuk menggali sejumlah informasi dari para pemangku kepentingan agar tercipa sistem yang sesuai dengan keinginan dan kebutuhan pengguna (user). Kelompok diskusi fokus dihadiri oleh tiga orang mahasiswa sebagai perwakilan dari masingmasing UKM. Perwakilan dari UKM merupakan mahasiswa yang terlibat sebagai pengurus inti UKM. Pihak manajemen dihadiri oleh kepala bagian kemahasiswaan dan wakil rektor bidang kemahasiswaan. Hasil dari kelompok diskusi fokus diperoleh informasi bahwa yang menjadi kebutuhan dan keinginan mendasar dari user antara lain sistem informasi yang bersifat fleksibel dapat diakses kapan pun, terintegrasi dengan Sistem Informasi Mahasiswa (SIMAS) dan sistem informasi kemahasiswaan. Adanya kebutuhan terhadap fitur aktivitas organisasi yang berkaitan dengan formulir pendaftaran dan kuota anggota dari masing-masing UKM. Proses pengajuan dana anggaran kegiatan Ormawa beserta pengelolaan korespondensi dan tanda tangan secara digital. Berdasarkan pada kebutuhan dan keinginan tersebut maka rancangan sistem informasi Ormawa yang sesuai untuk dikembangkan adalah yang berbasis web dengan jaringan online dengan nama Ormawasite. Sistem informasi berbasis situs web merupakan kumpulan laman berdomain yang menghubungkan sejumlah dokumen dengan laman web yang terkait serta dapat menampilkan informasi secara online [1]. Rancangan sistem informasi Ormawa yang dikembangkan tersebut menggunakan teknologi browser yang terhubung dengan jaringan internet [12] dan tersimpan pada hosting yang telah dimiliki oleh institusi sehingga akan lebih mudah untuk pengelolaannya [2]. Pengembangan difokuskan pada pengelolaan dokumen dan keuangan dalam rangka menata ulang dokumen dan mempercepat proses pencairan dana anggaran Ormawa dengan kontrol dari bagian kemahasiswaan [13]. Monitoring menjadi kewenangan dari bagian kemahasiswaan, oleh karena itu koneksi jaringan dibuat secara online dalam rangka mempermudah pelaksanaan pengendalian internal terhadap Ormawa. Berdasarkan pada kebutuhan dan keinginan user maka diperoleh informasi perbandingan antara sistem 
informasi Ormawa berbasis cloud dan web, seperti yang tercantum pada Tabel 1, perihal Perbandingan Sistem Informasi Ormawa yang dikembangkan.

Tabel 1. Perbandingan Sistem Informasi Ormawa

\begin{tabular}{|c|c|}
\hline Sistem Google Drive & Sistem Ormawasite \\
\hline \multicolumn{2}{|c|}{ Program Kerja (Proker) dan Anggaran } \\
\hline $\begin{array}{l}\text { 1. Pendaftaran anggota Ormawa dan presensi kehadiran } \\
\text { kegiatan menggunakan google form. Aktivitas program kerja } \\
\text { menggunakan google sheet dan program excel }\end{array}$ & $\begin{array}{l}\text { 1. Setiap pengurus Ormawa dapat melakukan login dan } \\
\text { inputan yang berkaitan dengan proker dan anggaran. }\end{array}$ \\
\hline $\begin{array}{l}\text { 2. Pengajuan dan pelaporan dana anggaran dilakukan secara } \\
\text { manual dengan scan dokumen dan diunduh ke google drive }\end{array}$ & $\begin{array}{l}\text { 2. Fitur-fitur terkait aktivitas dan pendanaannya, } \\
\text { meliputi pendaftaran anggota, presensi, jenis }\end{array}$ \\
\hline Ormawa dilengkapi dengan hard copy ke bagian kemahasiswaan & $\begin{array}{l}\text { kegiatan, pengajuan dan pelaporan anggaran, serta } \\
\text { pengkinian informasi kegiatan Ormawa }\end{array}$ \\
\hline \multicolumn{2}{|c|}{ Sistem Informasi } \\
\hline 1. Cloud (google drive dan google sheet) & 1. Web dan online \\
\hline \multicolumn{2}{|c|}{ Proses Bisnis } \\
\hline 1. Setiap Ormawa menggunakan akun resmi @ perbanas.ac.id & $\begin{array}{l}\text { 1. Setiap pengurus Ormawa login menggunakan } \\
\text { Nomor Induk Mahasiswa (NIM) yang terintegrasi } \\
\text { dengan Sistem Informasi Kemahasiswaan dan } \\
\text { Sistem Informasi Mahasiswa (Simas) }\end{array}$ \\
\hline $\begin{array}{l}\text { 2. Media penyimpnaan berupa google drive yang terhubung } \\
\text { dengan bagian kemahasiswaan dan Badan Eksekutif } \\
\text { Mahasiswa (BEM) }\end{array}$ & $\begin{array}{l}\text { 2. Seluruh proker, anggaran dan pelaporan tersimpan } \\
\text { dalam bentuk dashboard dan terintegrasi dengan } \\
\text { google drive } \\
\text { 3. Monitoring dilakukan oleh bagian kemahasiswaan }\end{array}$ \\
\hline
\end{tabular}

\subsection{Rancangan Sistem}

Analisis kebutuhan menjadi dasar dari rancangan perangkat lunak yang dapat diestimasikan sebelum pembuatan bahasa pemrograman (coding). Tahapan ini menitik beratkan pada struktur data, arsitektur perangkat lunak, representasi interface dan algoritma prosedural. Pada rancangan pengembangan sistem tidak terlepas dari database sebagai data dasar yang dirancang, dibangun, dan diisi dengan data untuk tujuan tertentu. Sifatnya koheren dan secara logis memiliki beberapa makna yang melekat dan dasar dari sistem manajemen database (Database Management System/DBMS). DBMS merupakan kumpulan program yang memungkinkan user untuk membuat dan memelihara database berupa perangkat lunak [14]. DBMS merupakan hasil pengelolaan database melalui proses perekaman dan pemeliharaan data operasional organisasi secara lengkap melalui komputer [15]. Berkaitan dengan database tersebut, Ormawasite menggunakan database postgree 5. Rancangan awal sistemnya menghasilkan Use Case Diagram (UCD), Activity Diagram (AD) dan Entity Relation Diagram (ERD).

\subsection{Pengembangan Sistem}

Pengembangan pada Ormawasite menggunakan bahasa pemrograman yang sesuai dengan basis web yaitu Hypertext Prepocessor yang dikenal dengan istilah PHP. Bahasa pemrograman tersebut digunakan bersamaan dengan Hyper Text Markup Language (HTML). Penempatan dan prosesnya pada server guna menghasilkan satu halaman web dengan tampilan terkini [16], [17]. Ormawasite menggunakan bahasa pemrograman HTML 5, PHP 7.018. Bagian dalam sistem dibangun dengan menggunakan framework codeigniter sebagai backend dan framework bootstrap sebagai fronted.

\subsection{Pengujian}

Pengujian Ormawasite sebagai suatu sistem informasi yang dikembangkan menggunakan uji black box. Teknik pengujian dengan black box lebih kepada pengujian perangkat lunak sistem yang dikembangkan. Pengujian lebih kepada output yang dihasilkan sebagai respon terhadap input dan kondisi eksekusi yang dipilih [18]. Pengujian penggunaan Ormawasite menggunakan kuesioner berskala likert dengan skala 1-5.

\subsection{Implementasi dan Pemeliharaan}

Implementasi dari semua rancangan sistem melalui tahapan coding dilanjutkan dengan penggunaan perangkat lunak sebagai tools. Sistem operasi yang digunakan adalah windows 10 dengan notepad ++ sebagai text editor yang fungsinya untuk penulisan kode program. Koneksi antara server dan browser menggunakan apache sembari mengirimkan file antara client dan server. 


\section{HASIL DAN ANALISIS}

Penelitian ini menghasilkan aplikasi berbasis web sebagai sistem informasi Ormawa yang dikenal dengan Ormawasite. Pengembangan dari Ormawasite dilakukan dalam rangka memberikan kemudahan bagi sejumlah UKM untuk melaksanakan sejumlah proker dan pengajuan dana anggaran selama satu tahun (satu periode). Ormawasite juga berguna dalam hal penataan dokumen-dokumen Ormawa terutama yang berkaitan dengan daftar anggota dari masing-masing UKM. Ormawasite juga mempermudah tugas dari bagian kemahasiswaan dalam melakukan monitoring pelaksanaan proker dan penggunaan dana anggaran. Sistem informasi ini juga terintegrasi dengan sistem informasi mahasiswa dan bagian kemahasiswaan. Beberapa fitur Ormawasite juga terintegrasi juga dengan aplikasi google meet dan zoom yang dapat digunakan secara langsung oleh UKM untuk melaksanakan sejumlah kegiatannya. Ormawasite juga terhubung dengan media sosial instagram dari masing-masing UKM. Keberadaan Ormawasite ini dalam jangka panjangnya berkaitan dengan tata kelola perguruan tinggi dalam rangka mencapai visi perguruan tinggi yang unggul, terkemuka dan global. Pencapaian visi tersebut dicanangkan dengan penggunaan sistem informasi yang diikuti juga oleh Ormawa.

\subsection{Use Case Diagram}

Use Case Diagram (UCD) seperti yang tercantum pada Gambar 2, merupakan tahapan yang digunakan dalam Unifield Modelling Language (UML) sebagai ilustrasi pengembangan prototype sistem Ormawa. UCD pada penelitian ini melibatkan tiga peran yaitu bagian kemahasiswaan, BEM dan pengurus inti dari masing-masing UKM yang tergabung dalam Ormawa. Bagian kemahasiswaan berperan melakukan setup periode kepengurusan, menambahkan pengurus inti BEM serta melakukan monitoring dan persetujuan aktivitas BEM. Peranan BEM adalah setup periode, agenda dan monitoring persetujuan aktivitas serta batas anggaran dari masing-masing UKM.

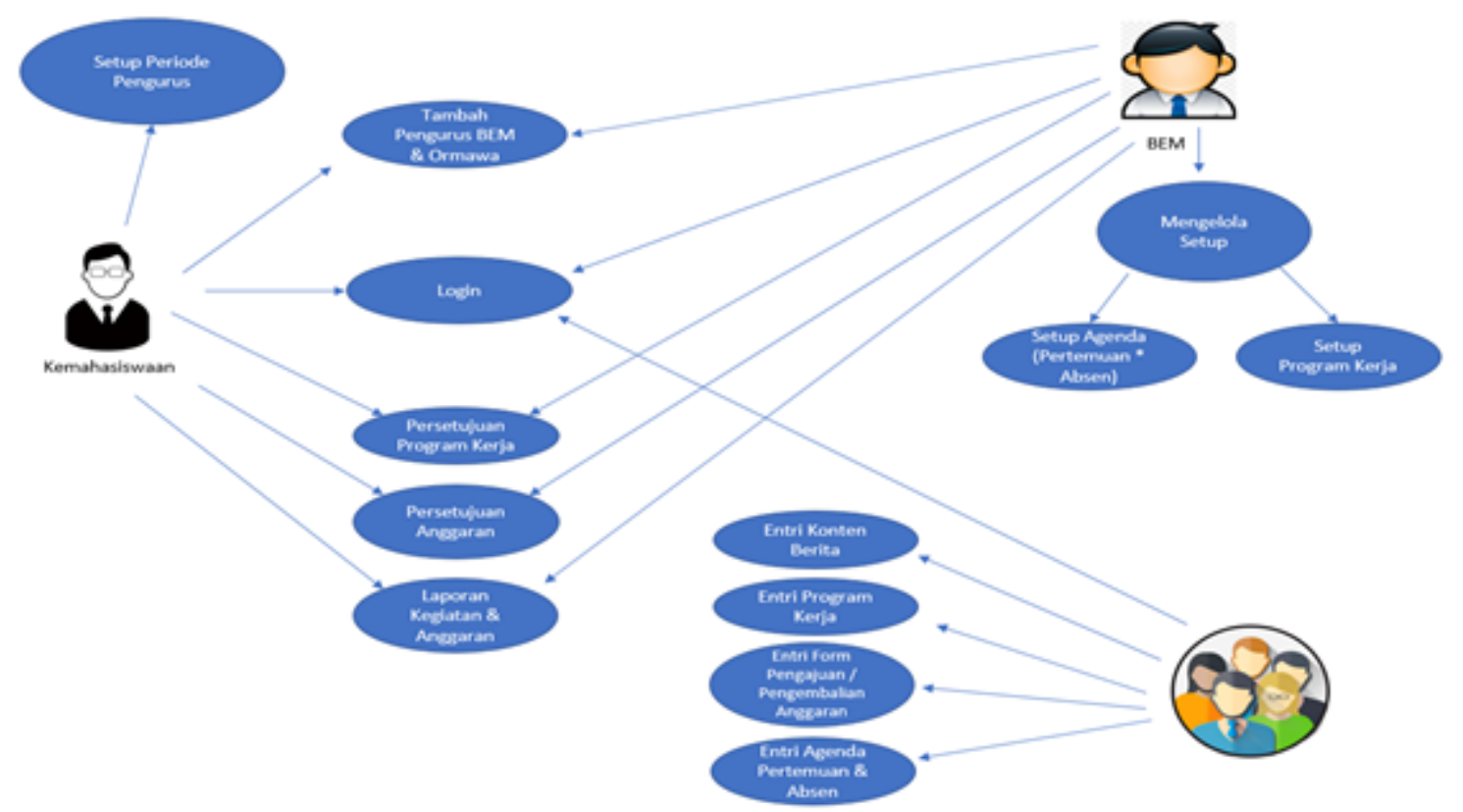

Gambar 2. Use Case Diagram

\subsection{Activity Diagram}

Alur bisnis proses aktivitas Ormawasite tercantum pada Gambar 3. Proses bisnis awal kepengurusan Ormawa lebih dulu dilakukan setup periode pengurus Ormawa oleh bagian kemahasiswaan melalui sistem informasi kemahasiswaan. BEM selanjutnya melakukan setup agenda kegiatan dan anggaran masing-masing UKM. Masing-masing pengurus inti UKM selanjutnya melakukan entry tambah anggota, program kerja dan anggaran selama satu periode (dua semester) dilanjutkan dengan presentasi proker dan anggaran kepada BEM dan bagian kemahasiswaan. Usulan proker dan anggaran disampaikan kepada pihak manajemen universitas oleh bagian kemahasiswaan dalam rangka memperoleh persetujuan. Pelaksanaan proker dan pencairan dana anggaran dilakukan setelah memperoleh persetujuan tersebut, selanjutnya pengajuan dan penggunaan dana anggaran beserta laporan kegiatan dapat dilakukan oleh masing-masing UKM melalui persetujuan BEM dan bagian kemahasiswaan. Masing-masing pengurus UKM melakukan entry setiap agenda kegiatan dan memberikan keterangan lulus bagi setiap anggota binaannya. Secara umum Ormawa dapat juga melakukan pengkinian isi berita kegiatan ormawa pada laman Ormawasite. 


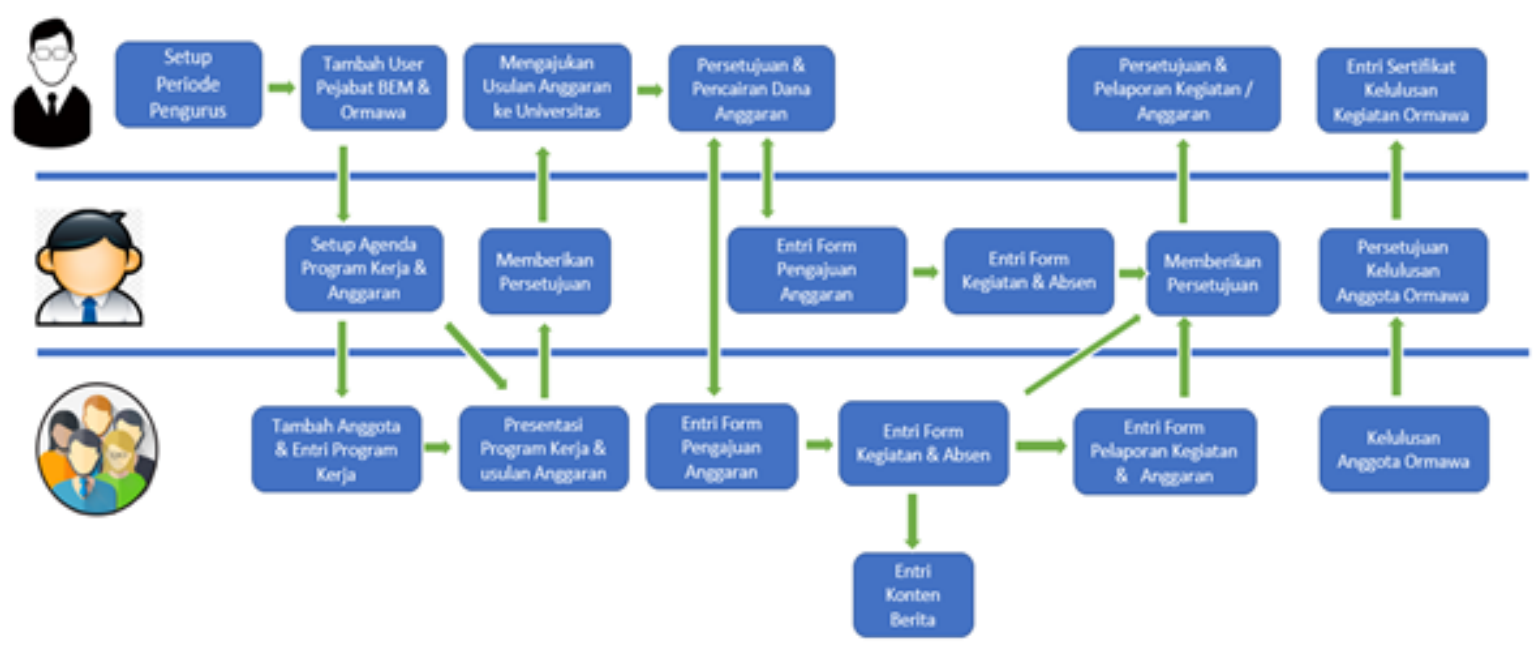

Gambar 3. Activity Diagram

\subsection{Entity Relation Diagram (ERD)}

Gambaran secara lengkap struktur database yang meliputi arti, hubungan serta batasan-batasan dari rancangan bisnis proses Ormawasite tercantum pada Gambar 4, tentang ERD. Rancangan ERD Ormawasite merupakan rancangan database yang dikembangkan secara konseptual. ERD tersebut menggambarkan hubungan atribut dalam entitas dan hubungan antar entitas dalam rangka mempermudah penggunaan atribut data yang sama antar entitas. Seluruh entitas pada aktivitas bisnis proses Ormawasite Gambar 4 dikelompokkan dalam atribut data agar membentuk entitas sederhana, fleksibel dan menghindari redudansi, sehingga pada tahap perancangan ini memberikan gambaran mengenai database yang diterapkan dalam sistem dengan baik.

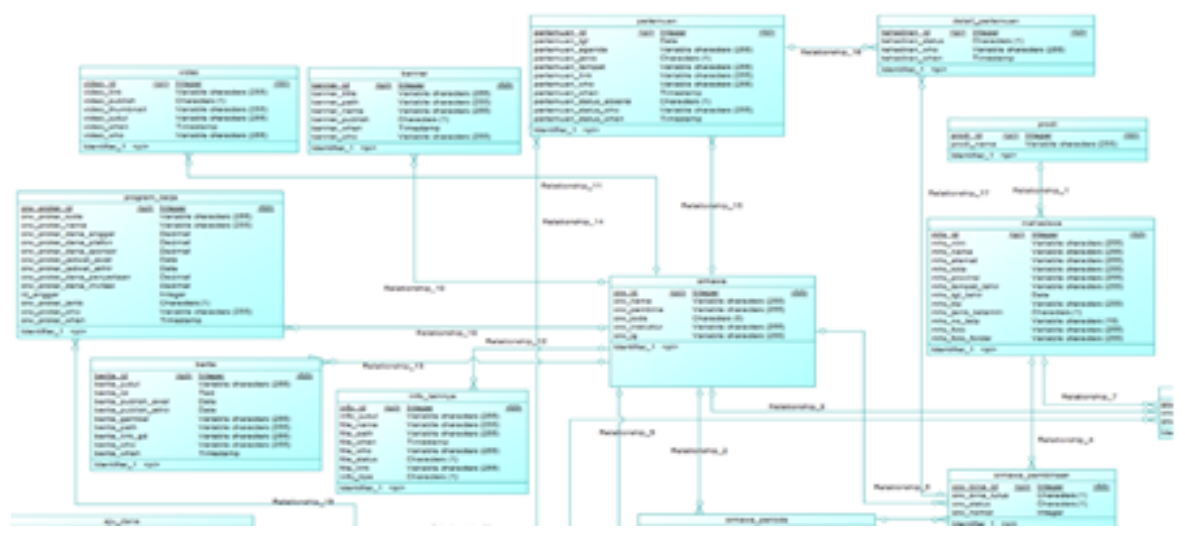

Gambar 4. Entity Relation Diagram (ERD)

\subsection{Pengembangan Sistem}

Unit kerja Kemahasiswaan terlebih dahulu mendaftarkan sejumlah pengurus Ormawa pada Sistem Informasi (Sisfo) Kemahasiswaan berdasarkan NIM, yang terintegrasi dengan Ormawasite. Bagian kemahasiswaan juga sekaligus memonitoring user dari masing-masing UKM. Laman login dari Ormawasite melalui www.ormawa.perbanas.ac.id/login. Login menggunakan NIM sebagai isian user. NIM tersebut secara langsung akan mengenali nama UKM user. Kata kunci (password) sesuai dengan kata kunci pada masing-masing Sistem Informasi Mahasiswa (SIMAS). Tampilan halaman login Ormawasite tercantum pada Gambar 5. 


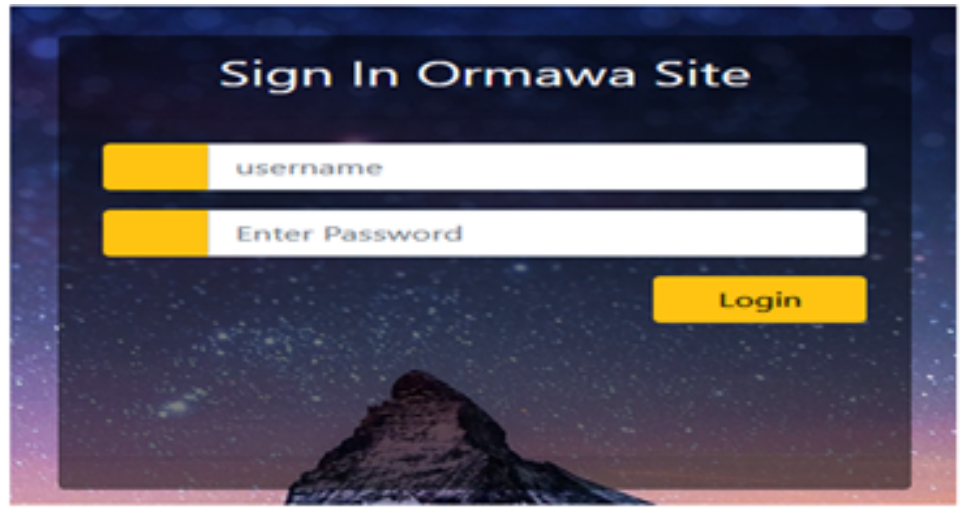

Gambar 5. Halaman Login

Dashboard admin merupakan landing page yang digunakan oleh pengguna admin yaitu sejumlah pengurus Ormawa dari 23 UKM. Dashboard admin terdiri dari Setup dan Proses. Menu setup meliputi setup anggota dan setup pertemuan. Setup anggota untuk pendaftaran anggota dari masing-masing UKM yang disebut sebagai mahasiswa binaan. Setup pertemuan digunakan untuk membuat daftar pertemuan baik yang dilaksanakan secara daring maupun secara luring. Namun, selama masa pandemi kegiatan pertemuan Ormawa lebih banyak dilaksanakan secara daring. Pada menu daftar pertemuan terdapat isian yang berkaitan dengan informasi tempat dan tanggal penyelenggaraan. Menu daftar pertemuan menjadi kewenangan sekretaris dan divisi Hubungan Masyarakat (HuMas) dari masing-masing UKM. User dapat menambahkan pertemuan maupun mengubah jadwal pertemuan. Media pertemuan Ormawa secara daring menggunakan link dari aplikasi Zoom, sedangkan pertemuan secara luring menggunakan menu peminjaman ruangan. Tampilan dari dashboard admin dengan menu setup tercantum pada Gambar 6, perihal Menu Daftar Anggota dan Agenda.

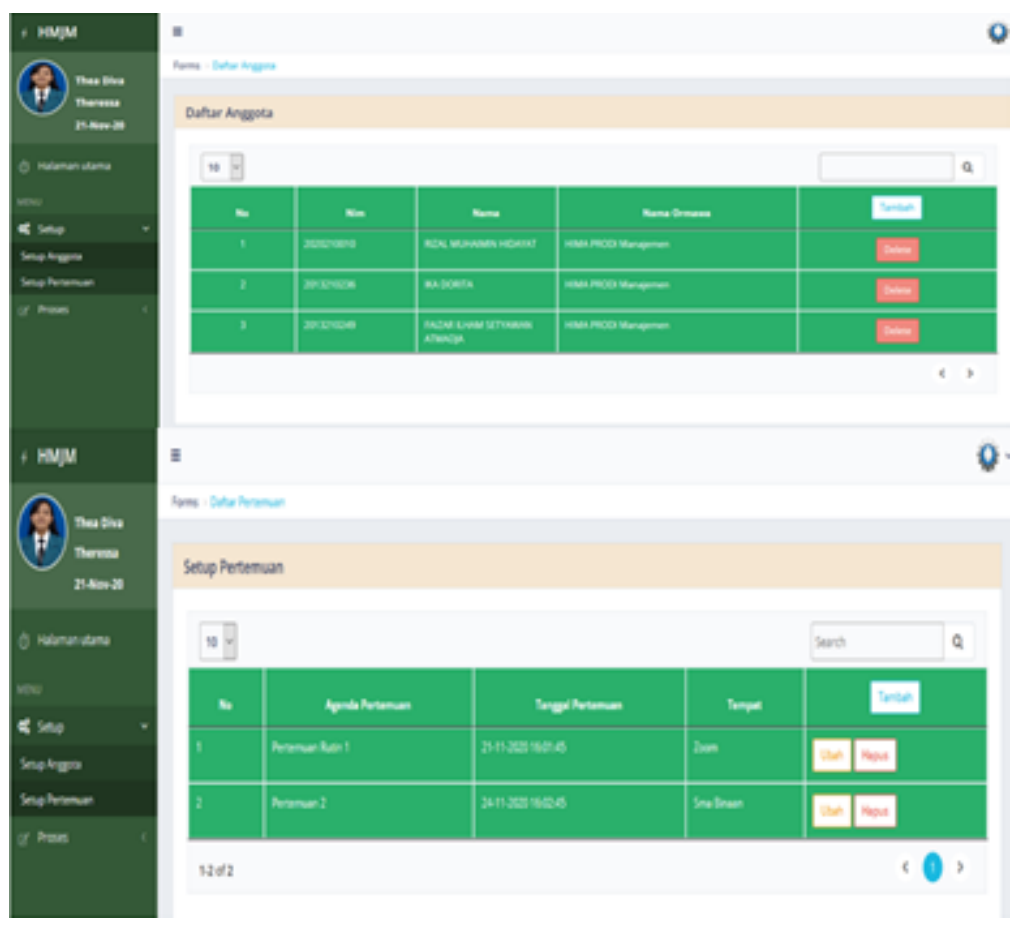

Gambar 6. Menu Daftar Anggota dan Agenda

Menu proses berkaitan dengan pengelolaan dokumentasi kegiatan dan keuangan Ormawa. Fitur-fiturnya terdiri dari absensi pertemuan, program kerja (proker), pengajuan dana, pemakaian dana, info lainnya, persetujuan pengajuan dan pemakaian dana, spanduk (banner) elektronik dan video. Menu proses merupakan kelanjutan dari menu setup. Inputan pertemuan akan terhitung pada menu absensi pertemuan, seperti pada Gambar 7, yaitu Menu Absensi Ormawa. 


\section{Absen Pertemuan}

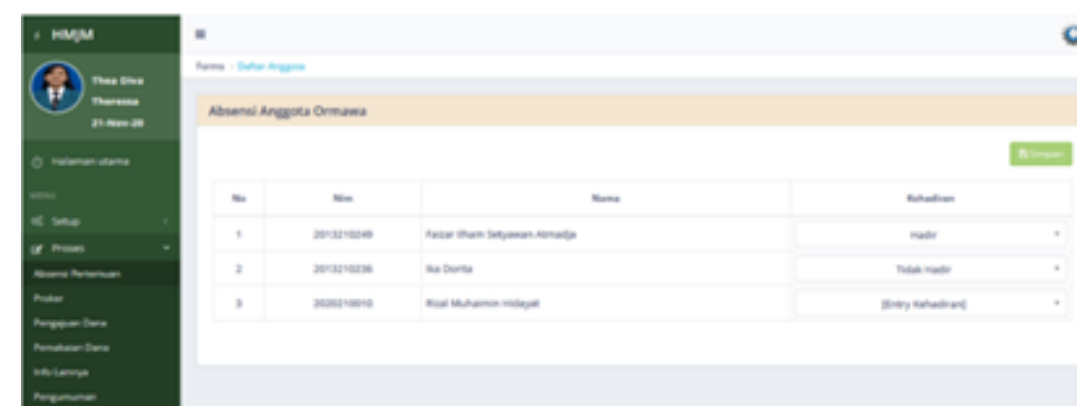

Gambar 7. Menu Absensi Ormawa

Menu proker digunakan untuk menginput sejumlah kegiatan Ormawa selama satu tahun. Pelaksanaan setiap proker tidak terlepas dari pendanaan, sehingga inputan proker secara langsung terhubung dengan menu pengajuan dan pemakaian dana anggaran. Pengajuan dan pemakaian dana anggaran dari masing-masing UKM, prosesnya harus diverifikasi lebih dahulu oleh BEM sebelum dilaporkan ke bagian kemahasiswaan. Menu proker, pengajuan dan pemakaian dana anggaran seperti pada Gambar 8 , yaitu Menu Proker, Pengajuan dan Pemakaian Dana.

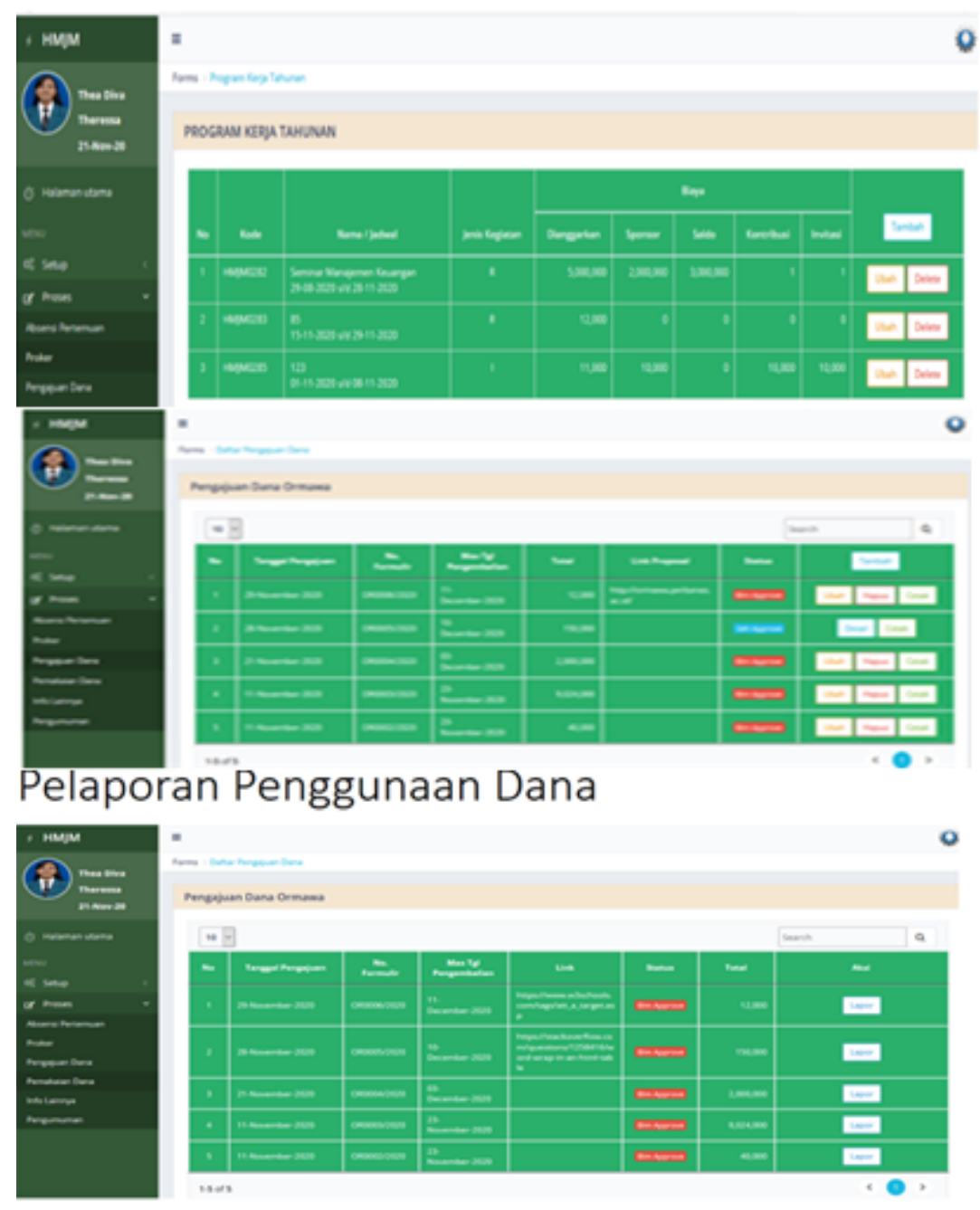

Gambar 8. Menu Proker, Pengajuan dan Pemakaian Dana

Fitur tambahan yang terdapat pada Ormawasite adalah menu info lainnya. Menu tersebut terdiri dari menu spanduk elektronik (e-banner) dan video, yang dapat digunakan untuk memuat sejumlah informasi lainnya seperti pengumuman secara elektornik. Spanduk elektronik hanya dapat memuat gambar dengan kapasitas maksimal tiga Megabyte (Mb) dengan format Join Photographic Group 
(JPG), sedangkan kapasitas maksimal dari video maksimal hanya dapat memuat tiga. Apabila ada penambahan video maka salah satu dari ketiga video yang diunggah harus dihapus terlebih dahulu. Fitur tambahan berupa menu info lainnya tercantum pada Gambar 9.
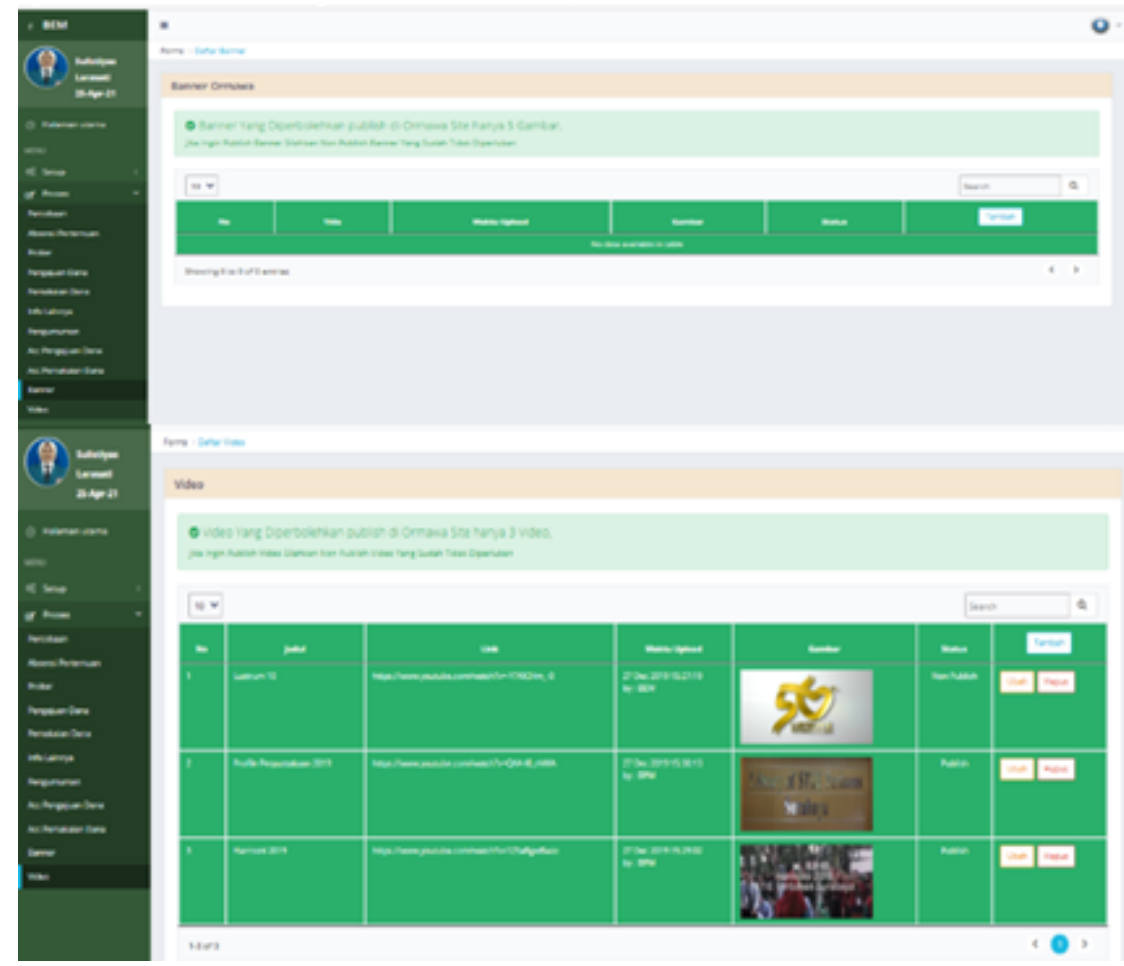

Gambar 9. Fitur Tambahan

Inputan informasi lainnya dalam bentuk gambar maupun video dapat dilihat pada laman www.ormawa.perbanas.ac.id. Sejumlah mahasiswa binaan dari 23 UKM dapat mengetahui beragam informasi dari masing-masing UKM melalui laman tersebut. Tampilan dari laman Ormawasite tersebut tercantum pada Gambar 10, perihal Tampilan Ormawasite.

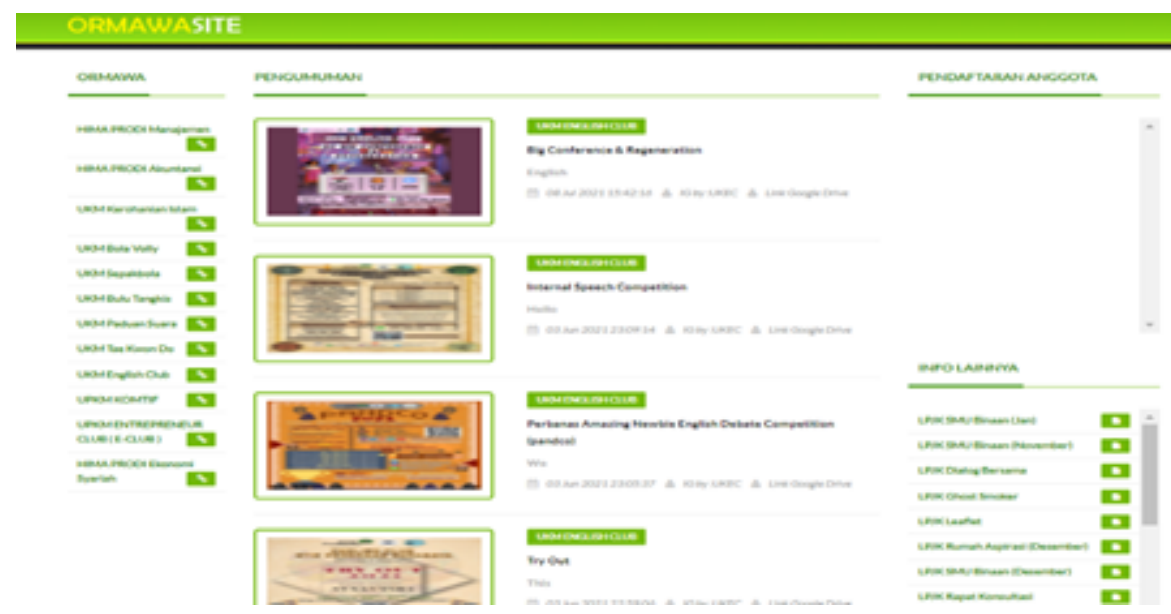

Gambar 10. Tampilan Ormawasite

\subsection{Hasil Pengujian}

Pengujian sistem Ormawasite menggunakan blackbox testing yang bertujuan untuk memastikan bahwa sistem yang telah dikembangkan tersebut dapat dioperasikan dengan baik oleh user secara khusus yaitu pengurus Ormawa. Hasil uji blackbox telah sesuai dengan hasil yang diharapkan, artinya fungsi-fungsi sistem Ormawasite telah dapat dioperasikan sesuai dengan yang diharapkan. Hasil uji blackbox tercantum pada Tabel 2. 
Tabel 2. Hasil Uji Blackbox

\begin{tabular}{|c|c|c|c|c|}
\hline Identitas & Fitur & Deskripsi Pengujian & Hasil yang Diharapkan & Kesimpulan \\
\hline A001 & Setup periode & $\begin{array}{l}\text { Mengisi tahun periode pengurusan } \\
\text { Ormawa sesuai tahun akademik }\end{array}$ & $\begin{array}{l}\text { Hasil tahun setup sesuai dengan } \\
\text { tahun aktif yang berjalan }\end{array}$ & Berhasil \\
\hline A002 & Setup periode & $\begin{array}{l}\text { Mengisi tahun periode pengurusan } \\
\text { Ormawa dengan tahun tidak sesuai } \\
\text { dengan tahun akademik }\end{array}$ & $\begin{array}{l}\text { Hasil akan ada notifikasi memeriksa } \\
\text { kembali tahun akademik yang } \\
\text { sedang aktif berjalan }\end{array}$ & Berhasil \\
\hline B001 & Login Pengurus Ormawa & $\begin{array}{l}\text { Mengisi NIM dan tabel pengurus } \\
\text { Ormawa sesuai dengan NIM yang berada } \\
\text { di database bagian kemahasiswaan }\end{array}$ & $\begin{array}{l}\text { Menampilkan login berhasil dan } \\
\text { dapat menggunakan menu } \\
\text { Ormawasite }\end{array}$ & Berhasil \\
\hline B002 & Login pengurus Ormawa & $\begin{array}{l}\text { Mengisi NIM yang tidak sesuai dengan } \\
\text { NIM yang aktif pada database bagian } \\
\text { kemahasiswaan }\end{array}$ & $\begin{array}{l}\text { Sistem akan menolak dan } \\
\text { menampilkan pemberitahuan NIM } \\
\text { login gagal }\end{array}$ & Berhasil \\
\hline $\mathrm{C} 001$ & Entry kegiatan dan absen & $\begin{array}{l}\text { Mengisi kegiatan sesuai dengan proker } \\
\text { dengan setup proker yang telah disetujui }\end{array}$ & $\begin{array}{l}\text { Sistem akan menampilkan kegiatan } \\
\text { sukses ditambahkan }\end{array}$ & Berhasil \\
\hline $\mathrm{CO02}$ & Entry kegiatan dan absen & $\begin{array}{l}\text { Mengisi kegiatan tidak sesuai dengan } \\
\text { proker }\end{array}$ & $\begin{array}{l}\text { Sistem akan menampilkan kegiatan } \\
\text { yang tidak ada pada program kerja }\end{array}$ & Berhasil \\
\hline D001 & $\begin{array}{l}\text { Entry pengajuan dana } \\
\text { anggaran }\end{array}$ & $\begin{array}{l}\text { Mengisi pengajuan anggaran sesuai } \\
\text { dengan nominal atau lebih kecil dari dana } \\
\text { anggaran yang telah disetujui }\end{array}$ & $\begin{array}{l}\text { Sistem akan menampilkan anggaran } \\
\text { sukses diajukan }\end{array}$ & Berhasil \\
\hline D002 & $\begin{array}{l}\text { Entry pengajuan dana } \\
\text { anggaran }\end{array}$ & $\begin{array}{l}\text { Mengisi pengajuan dana anggaran lebih } \\
\text { besar dari dana anggaran yang telah } \\
\text { disetujui }\end{array}$ & $\begin{array}{l}\text { Sistem akan menampilkan dana anggaran } \\
\text { melebihi dana anggaran yang telah disetujui }\end{array}$ & Berhasil \\
\hline E001 & $\begin{array}{l}\text { Entry pengembalian dana } \\
\text { anggaran }\end{array}$ & $\begin{array}{l}\text { Mengisi pengembalian dana anggaran } \\
\text { sesuai dengan nominal dari pengajuan } \\
\text { dana anggaran }\end{array}$ & $\begin{array}{l}\text { Sistem akan menampilkan dana } \\
\text { anggaran sukses diajukan }\end{array}$ & Berhasil \\
\hline E002 & $\begin{array}{l}\text { Entry pengembalian dana } \\
\text { anggaran }\end{array}$ & $\begin{array}{l}\text { Mengisi pengembalian dana anggaran } \\
\text { tidak sesuai dengan nominal dari } \\
\text { pengajuan dana anggaran }\end{array}$ & $\begin{array}{l}\text { Sistem akan menampilkan informasi } \\
\text { Periksa Kembali Pengembalian Anggaran }\end{array}$ & Berhasil \\
\hline
\end{tabular}

Evaluasi terhadap penggunaan dan kemanfaatan Ormawasite bagi user menggunakan uji beta, setelah dilakukan blackbox testing. Uji beta menggunakan kuesioner dengan skala likert pada 30 responden. Pengukuran pada uji beta meliputi tujuh pertanyaan yang berkaitan dengan kemudahan dan penggunaan Ormawasite. Jawaban dari masing-masing responden dibobot dan dibandingkan dengan skor ideal dari masing-masing pertanyaan. Rincian perhitungan pembobotan tercantum pada Tabel 3, perihal Perhitungan Jawaban Responden.

Tabel 3. Hasil Perhitungan Jawaban Responden

\begin{tabular}{|c|c|c|c|c|c|c|c|c|}
\hline Skala Likert & Bobot Likert & $\begin{array}{l}\text { Pertanyaan } \\
\text { ke-1 }\end{array}$ & $\begin{array}{l}\text { Pertanyaan } \\
\text { ke-2 }\end{array}$ & $\begin{array}{l}\text { Pertanyaan } \\
\text { ke-3 }\end{array}$ & $\begin{array}{l}\text { Pertanyaan } \\
\text { ke-4 }\end{array}$ & $\begin{array}{l}\text { Pertanyaan } \\
\text { ke-5 }\end{array}$ & $\begin{array}{l}\text { Pertanyaan } \\
\text { ke-6 }\end{array}$ & $\begin{array}{l}\text { Pertanyaan } \\
\text { ke-7 }\end{array}$ \\
\hline Sangat Tidak Setuju & 1 & 0 & 0 & 1 & 1 & 1 & 0 & 0 \\
\hline Tidak Setuju & 2 & 0 & 1 & 0 & 0 & 1 & 2 & 1 \\
\hline Netral & 3 & 5 & 5 & 9 & 3 & 3 & 5 & 8 \\
\hline Setuju & 4 & 14 & 15 & 12 & 14 & 15 & 13 & 12 \\
\hline Sangat Setuju & 5 & 11 & 9 & 8 & 12 & 10 & 10 & 9 \\
\hline Bobot & & 126 & 122 & 116 & 126 & 122 & 121 & 119 \\
\hline \multicolumn{2}{|c|}{$\begin{array}{l}\text { (Skala5 } \times \text { jumlah responden) } \\
=5 \times 30\end{array}$} & 150 & 150 & 150 & 150 & 150 & 150 & 150 \\
\hline \multicolumn{2}{|c|}{ Persentase $(\%)$} & $84 \%$ & $81,33 \%$ & $77,33 \%$ & $84 \%$ & $81,33 \%$ & $80,67 \%$ & $79,33 \%$ \\
\hline
\end{tabular}

Hasil pembobotan dibagi jumlah pertanyaan secara keseluruhan. sehingga hasil uji beta memperoleh nilai rata-rata sebagai berikut:

$$
\begin{aligned}
& R=\frac{(84 \%)+(81,33 \%)+(77,33 \%)+(84,00 \%)+(81,33 \%)+(80,67 \%)+(79,33 \%)}{7} \\
& R=81,14 \%
\end{aligned}
$$

Nilai rata-rata penggunaan Ormawasite berkaitan dengan manfaat dan kemudahan penggunaannya memperoleh hasil $81,14 \%$ berada pada interval sangat setuju. Berdasarkan interval tersebut, maka penggunaan Ormawasite secara khusus bagi user memberikan manfaat dan kemudahan pada pengelolaan aktivitas dan dana anggaran Ormawa. Manfaat yang diperoleh adalah pengelolaan aktivitas dan keuangan lebih cepat prosesnya dibandingkan dengan yang sebelumnya memerlukan waktu proses selama tujuh hari karena masih bersifat manual dan belum terintegrasi dengan unit kemahasiswaan. Penggunaan ormawasite memberikan kecepatan waktu proses 
dari tujuh hari menjadi satu hari. Mahasiswa juga dapat membuat laporan dan melaporkan tanpa harus datang ke kampus karena Ormawasite jaringannya sudah online.

Penelitian sebelumnya juga melakukan uji alpha dengan menggunakan black box dan uji beta. Namun, pengujian hanya pada sistem informasi anggaran (budgeting) Ormawa. Semua fungsi dapat berjalan dengan baik berdasarkan uji alpha. Pada uji beta hanya menggunakan 15 responden dengan persentase akhir 82,50\%. Berdasarkan hasil tersebut sejumlah responden setuju tidak ada kesalahan pada sistem anggaran Ormawa [4]. Penelitian sebelumnya juga berbasis situs web dengan metode SAW untuk penilaian kondisi administrasi Ormawa. Namun, pada hasil pengujiannya metode tersebut tidak dapat digunakan untuk menentukan kondisi Ormawa dengan baik, karena penilaiannya bersifat relatif [8], sehingga menghasilkan perbedaan penilaian pada kondisi yang sama. Penelitian sebelumnya masih berfokus pada satu fitur yang ada dalam satu sistem dan belum terintegrasi dengan unit kerja lainnya.

\section{KESIMPULAN}

Berdasarkan pada hasil penggujian blackbox, fungsi dari masing-masing Ormawasite telah memenuhi hasil yang diharapkan, sedangkan berdasarkan hasil evaluasi penggunaan Ormawasite dengan uji beta mengungkapkan bahwa penggunaan Ormawasite memberikan manfaat dalam pengelolaan aktivitas dan keuangan secara efektif dan efisien. Hasil dari kedua uji tersebut menjadi dasar untuk impelemntasi Ormawasite dan telah digunakan oleh 23 UKM sebagai bagaian dari Ormawa UHW Perbanas Surabaya. Keberadaan Ormawasite yang terintegrasi tidak hanya memberikan manfaat bagi Ormawa tetapi juga terhadap bagian kemahasiswaan yang berperan dalam monitoring dan pengendalian secara internal. Keberlangsungan pengelolaan Ormawa tida terlepas dari hadirnya inovasi teknologi yang berpartisipasi mewujudkan harapan dari pemangku kepentingan pada perguruan tinggi UHW Perbanas Surabaya, karena mengintegrasikan aliran informasi secara efektif sehingga terbentuk kerja sama tim dan sekaligus memperkuat pengawasan organisasi. Implementasi Ormawasite yang terintegrasi membedakan hasil penelitian ini dengan penelitian sebelumnya.

Pengembangan lebih lanjut terhadap Ormawasite adalah adanya fitur tanda tangan elektronik. Fitur tersebut belum ada pada Ormawasite saat ini, karena masih memerlukan standar prosedur operasional yang baku dan disetujui oleh manajemen perguruan tinggi. Penggunaan tanda tangan elektronik juga berkaitan dengan kewenangan dan privasi sehingga diperlukan sistem keamanan yang tinggi dan terjamin.

\section{UCAPAN TERIMA KASIH}

Terima kasih disampaikan kepada Pusat Penelitian dan Pengabdian Masyarakat (PPPM) Universitas Hayam Wuruk Perbanas d/n STIE Perbanas Surabaya yang telah mendukung dan mendanai penelitian terapan internal ini.

\section{REFERENSI}

[1] M. V. 1 Hasri and E. Sudarmilah, "Sistem Informasi Pelayanan Administrasi Kependudukan Berbasis Website Kelurahan Banaran,” Matrik: Jurnal Manajemen, Teknik Informatika, dan Rekayasa Komputer, vol. 20, no. 2, pp. 249-260, 2021.

[2] R. P. Soesanto, A. F. Rizana, and L. Andrawina, "Design of Reporting, Evaluation, and Monitoring Application for Student Organization in University," International Journal of Innovation in Enterprise System, vol. 3, no. 01, pp. 53-57, 2019.

[3] D. Abrego Almazán, Y. Sánchez Tovar, and J. M. Medina Quintero, "Influence of Information Systems on Organizational Results," Contaduria y Administracion, vol. 62, no. 2, pp. 321-338, 2017.

[4] S. Wulandari, "Rancang Bangun Sistem Informasi Budgeting Ormawa Universitas Muhammadiyah Semarang Berbasis Web," Jurnal Unimus Media Elektrika, vol. 13, no. 1, pp. 43-53, 2020.

[5] E. Bayangan-Cosidon, "Student Information System for Kalinga State University-Rizal Campus," International Journal of Management and Commerce Innovations, vol. 4, no. 2, pp. 223-229, 2016.

[6] C. Gürkut and M. Nat, "Important Factors Affecting Student Information System Quality and Satisfaction," Eurasia Journal of Mathematics, Science and Technology Education, vol. 14, no. 3, pp. 923-932, 2018.

[7] A. Al-Hunaiyyan, R. Alhajri, B. Alghannam, and A. Al-Shaher, "Student Information System: Investigating User Experience (UX)," International Journal of Advanced Computer Science and Applications, vol. 12, no. 2, pp. 80-87, 2021.

[8] D. P. Y. Ardiana, I. W. D. Suryawan, and E. Hartono, "Sistem Informasi Pengelolaan Administrasi Organisasi Kemahasiswaan di STMIK STIKOM Indonesia,” Jurnal Teknologi Informasi dan Komputer, vol. 4, no. 2, pp. 156-165, 2018.

[9] P. Isaias and T. Issa, "Information System Development Life Cycle Models," in High Level Models and Methodologies for Information Systems. Springer, New York, NY, 2015, ch. 2, pp. 21-40.

[10] Sadi, D. R. Lucitasari, and M. S. A. Khannan, "Designing Mobile Alumni Tracer Study System Using Waterfall Method : An Android Based," International Journal of Computer Networks and Communications Security, vol. 7, no. 9, pp. 196-202, 2019. 
[11] S. Balaji and M. Sundararajan Murugaiyan, "Waterfall Model Vs Agile: A Comparative Study On SDLC," International Journal of Information Technology and Business Management, vol. 2, no. 1, pp. 26-29, 2012.

[12] R. Ilham, N. Shonhadji, H. Yutanto, and D. Ekaningtyas, "Analysis of The Acceptance Factor of Android-Based Parking Information Systems in Indonesia," Communications - Scientific Letters of the University of Zilina, vol. 22, no. 2, pp. 97-106, 2020.

[13] C. Li, R. Yan, and Z. Bao, "Design and Implementation of University Student Organization Office Automation System," in 3rd International Conference on Control, Automation and Artificial Intelligence (CAII 2018). Beijing: Atlantis Press, 2018, pp. $36-40$.

[14] S. G. Shobha R. Bharamagoudar, Geeta R.B., "Web Based Student Information Management System," International Journal of Advanced Research in Computer and Communication Engineering, vol. 2, no. 6, pp. 2342-2348, 2013.

[15] H. Yutanto, R. Ilham, K. R. Salman, and Y. Effendi, "Pengembangan Sistem Informasi pada Local E-Govervenance untuk Peningkatan Kinerja Pelayanan Warga,” Jurnal Sistem Informasi Bisnis, vol. 9, no. 2, pp. 220-227, 2019.

[16] T. Amanatidis and A. Chatzigeorgiou, "Studying the Evolution of PHP Web Applications," Information and Software Technology, vol. 72, no. 3, pp. 48-67, 2016.

[17] C. F. Chuang and S. S. Chen, "Developing A Customized Web Mining System with PHP language: A Case of Kaohsiung Land Administration Website Data," Journal of Internet Technology, vol. 20, no. 6, pp. 1781-1786, 2019.

[18] M. Larrea, "Black-Box Testing Technique for Information Visualization. Sequencing Constraints with Low-Level Interactions," Journal of Computer Science and Technology (La Plata), vol. 17, no. 1, pp. 37-48, 2017. 